\title{
Heliconia phenotypic diversity based on qualitative descriptors
}

\author{
W.N.R. Guimarães ${ }^{1}$, L.S.S. Martins ${ }^{1}$, C.E.F. Castro ${ }^{2}$, \\ J.L.S. Carvalho Filho ${ }^{3}$ and V. Loges ${ }^{3}$ \\ ${ }^{1}$ Departamento de Biologia, Área de Genética, \\ Universidade Federal Rural de Pernambuco, Recife, PE, Brasil \\ ${ }^{2}$ Instituto Agronômico de Campinas, Campinas, SP, Brasil \\ ${ }^{3}$ Departamento de Agronomia, Área de Fitotecnia, \\ Universidade Federal Rural de Pernambuco, Recife, PE, Brasil \\ Corresponding author: W.N.R. Guimarães \\ E-mail:walmalamo@gmail.com
}

Genet. Mol. Res. 13 (2): 3128-3142 (2014)

Received March 26, 2013

Accepted December 4, 2013

Published April 17, 2014

DOI http://dx.doi.org/10.4238/2014.April.17.9

\begin{abstract}
The aim of this study was to characterize Heliconia genotypes phenotypically using 26 qualitative descriptors. The evaluations were conducted in five flowering stems per clump in three replicates of 22 Heliconia genotypes. Data were subjected to multivariate analysis, the Mahalanobis dissimilarity measure was estimated, and the dendrogram was generated using the nearest neighbor method. From the values generated by the dissimilarity matrix and the clusters formed among the Heliconia genotypes studied, the phenotypic characterizations that best differentiated the genotypes were: pseudostem and wax green tone (light or dark green), leaf-wax petiole, the petiole hair, cleft margin at the base of the petiole, midrib underside shade of green, wax midrib underside, color sheet (light or dark green), unequal lamina base, torn limb, inflorescence-wax, position of inflorescence, bract leaf in apex, twisting of the rachis, and type of bloom. These results will be applied in the preparation of a catalog for Heliconia descriptors, in the selection of different genotypes with most
\end{abstract}


promising characteristics for crosses, and for the characterization of new genotypes to be introduced in germplasm collections.

Key words: Phenotypic characterization; Germplasm collections; Plant morphology; Heliconiaceae; Dendrogram

\section{INTRODUCTION}

Heliconia plants are found in all tropical regions around the world. The economic importance of the Heliconia genus relies on its cultivation as an ornamental plant, which is used either as cut flowers or as garden and potted plants. In northeast Brazil, especially under the rainforest conditions in the State of Pernambuco, these plants have increased their production and most genotypes bloom throughout the year (Costa et al., 2007). This genus has great potential to be exploited in the international flower market by adjusting the quality of its products to international requirements, which can be achieved through genetic breeding programs.

In this context, germplasm characterization is a fundamental, quick, and affordable tool in the study of genetic diversity. Characterization consists of obtaining data that can be used to describe, identify, and differentiate genotypes within species, classes, or categories (de Vicente et al., 2005). In genetic terms, characterization can also refer to the detection of variation that results from differences in DNA sequences or specific genes. In phenotypic terms, characterization refers to describing the genetic diversity that is under environmental influence.

A germplasm represents the collection of genotypes, composed of any material that constitutes the physical basis of inheritance of a species, that are transmitted from one generation to another (IPGRI, 2001). Thus, germplasm characterization can be conducted using different methods, ranging from practices that involve the use of a list of morphological and agronomic descriptors to biochemical applications for detecting differences between isozymes, proteins, and molecular markers (de Vicente et al., 2005).

A descriptor is the term used to refer to an attribute or character that is observed or measured within genotypes of a germplasm collection (Cruz and Carneiro, 2003). Descriptors related to plant morphology have been employed in these collections for the determination of phenotypic diversity; i.e., the genetic diversity under the influence of the environment. The nature of these descriptors is usually multi-categorical and qualitative, related to plant structural features and morphology, or even qualitative binary when referring to the absence or presence of a certain characteristic.

Morphological descriptions have been used to differentiate some Heliconia cultivars and interspecific hybrids (Berry and Kress, 1991). Since the Heliconia genus was originally included in the Musaceae family (Cronquist, 1981), qualitative descriptors used in Musa spp germplasm (Silva et al., 1999) can be adapted to describe Heliconia genotypes. Some studies have been developed with the use of botanical, morphological, and agronomic descriptors of both quantitative and qualitative natures, or through the estimation of genetic parameters, which has contributed knowledge of the Heliconia germplasm (Criley, 2000; Castro et al., 2006, 2007; Loges et al., 2007; Costa et al., 2009a,b; Rocha et al., 2010).

The establishment and maintenance of a Heliconia germplasm collection is important for science and technology as well as for social and economic development, because it 
extends the possibilities of genotype exchanges between researchers (Castro, 2010). Furthermore, many genotypes are not under the protection of germplasm collection, which indicates a need to increase efforts to conserve Heliconia diversity. However, germplasm collections often store a large number of genotypes that need to be characterized.

The aim of this study was to phenotypically characterize Heliconia genotypes using 26 qualitative descriptors.

\section{MATERIAL AND METHODS}

\section{Experimental design}

The 22 genotypes evaluated were obtained through exchanges with research institutions and farmers from the States of Pernambuco (PE), Alagoas (AL), and São Paulo (SP) in Brazil (Table 1). Genotypes were planted in January 2007 in the Federal Rural University of Pernambuco's Heliconia Germplasm Collection (UFRPE-HCG) located in Camaragibe-PE at $8^{\circ} 1^{\prime} 19^{\prime \prime} \mathrm{S}, 34^{\circ} 59^{\prime} 33^{\prime \prime} \mathrm{W}$, and $100 \mathrm{~m}$ above sea level, in a 0.3 -ha experimental area. The average annual temperature of the region is $25.1^{\circ} \mathrm{C}$, and monthly rainfall is $176 \mathrm{~mm}$, with a maximum of $377 \mathrm{~mm}$ and a minimum of $37 \mathrm{~mm}$ (ITEP, 2008).

Soil management and NPK fertilization were undertaken in the experimental area, according to the soil analysis, by using $72 \mathrm{~g} /$ clump ammonium sulfate, $12 \mathrm{~g}$ /clump simple superphosphate, and $16 \mathrm{~g}$ /clump potassium chloride. Every three months, fertilization was complemented with $72 \mathrm{~g} /$ clump ammonium sulfate, $16 \mathrm{~g} /$ clump potassium chloride, and 13 $\mathrm{kg} /$ clump cattle manure. Mechanical weeding was performed in the period before flowering. A randomized block design was used with three replications per genotype. The plant spacing was $3.0 \mathrm{~m}$ between plants in the row and $4.0 \mathrm{~m}$ between rows. Irrigation was applied when needed by a sprinkling irrigation system using $2.5 \mathrm{~m}$ high gun sprinklers.

\section{Qualitative descriptors}

The evaluation started three months after planting the rhizomes. Five shoots of each of the three clumps per genotype were marked when they reached up to $15 \mathrm{~cm}$ tall. In the period from 2007 to 2008, five flowering stems per genotype were evaluated for the descriptors of the pseudostem, leaves, and inflorescences. These descriptors were elaborated according to previous Heliconia studies (Loges et al., 2007; Costa et al., 2009b), and were also based on the catalog of Musa spp descriptors (Silva et al., 1999), with modifications to accommodate the typical Heliconia morphological features observed, as described below:

\section{Pseudostem}

1 - pseudostem surface (shade of green): 1 ( ) pale; 2 ( ) yellow; 3 ( ) clear; 4 ( ) dark 2 - wax: 1 ( ) presence; 2 ( ) absence

3 - hair: 1 ( ) presence; 2 ( ) absence

4 - plant height: 1 ( ) short, less than $1.50 \mathrm{~m}$; 2 ( ) medium, 1.51 to 2.50 m mean; 3 ( ) tall, more than $2.50 \mathrm{~m}$ 


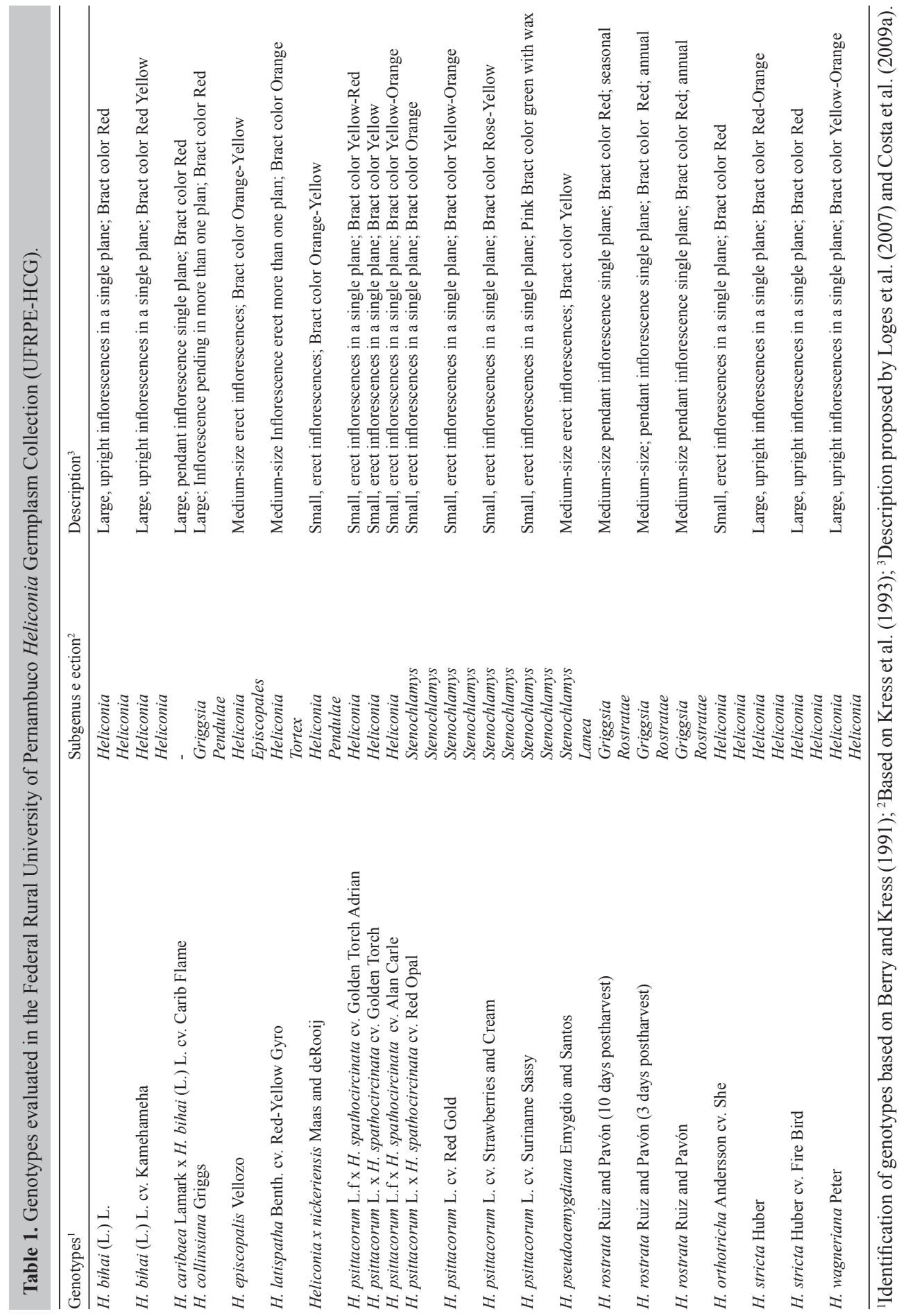




\section{Leaf}

5 - leaf underside green color: 1 ( ) pale; 2 ( ) yellow; 3 ( ) clear; 4 ( ) dark

6 - leaf upper side green color: 1 ( ) pale; 2 ( ) yellow; 3 ( ) clear; 4 ( ) dark

7 - reddish main vein leaf underside green color (antocianin presence): 1 ( ) very colorful; 2 ( ) rather colorful, average; 3 ( ) not colored

8 - reddish main vein leaf upper side green color (antocianin presence): 1 ( ) very colorful; 2 ( ) rather colorful, average; 3 ( ) not colored

9 - leaf margin color: 1 ( ) dark purple; 2 ( ) light purple; 3 ( ) absence

10 - leaf position: 1 ( ) erect; 2 ( ) pending; 3 ( ) arcade

11- dorsal wax: 1 ( ) a lot; 2 ( ) average; 3 ( ) low; 4 ( ) missing

12 - ventral wax: 1 ( ) a lot; 2 ( ) average; 3 ( ) low; 4 ( ) missing

13 - dorsal hair: 1 ( ) a lot; 2 ( ) average; 3 ( ) low; 4 ( ) missing

14 - ventral hair: 1 ( ) a lot; 2 ( ) average; 3 ( ) low; 4 ( ) missing

15 - leaf margins width (aid of calipers or tape measure)

16 - presence of leafblade stain: 1 ( ) spots rare; 2 ( ) a few spots; 3 ( ) unstained

17 - comparison of the base of the leafblade dimensions: (1) equal; 2 ( ) unequal; 3 ( ) variable in the same plant

18 - leafblade base form: 1 ( ) both bases abrupt; 2 ( ) both bases tapered; 3 ( ) abrupt and tapered base

19 - leafblade: 1 ( ) ripped (in genotype H. rostrata), 2 ( ) not ripped

20 - base of the petiole form: 1 ( ) winged with wrinkles; 2 ( ) winged without wrinkles; 3 ( ) not winged; 4 ( ) closed

21 - margins base: 1 ( ) very cleft; 2 ( ) cleft bit; 3 ( ) not cleft

22 - petiole margin shape: 1 ( ) wide open; 2 ( ) slightly open; 3 ( ) somewhat closed; 4 ( ) closed

23 - leaf arrangement (field assessment): 1 ( ) musoide; 2 ( ) zingiberoide; 3 ( ) canoide.

\section{Peduncle and inflorescence}

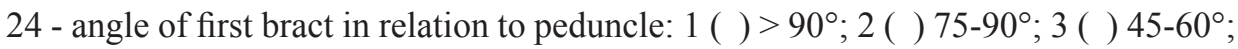
4 ( ) $15-30^{\circ} ; 5$ ( ) $0^{\circ}$

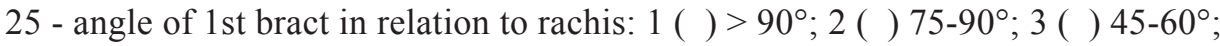
4 ( ) $15-30^{\circ} ; 5$ ( ) $0^{\circ}$

26 - bract with leaf at the end: 1 ( ) presence; 2 ( ) absence

27 - bract apex shape: 1 ( ) large (bowed); 2 ( ) narrow; 3 ( ) tapered

28 - wax: 1 ( ) a lot; 2 ( ) average; 3 ( ) low; 4 ( ) absent

29 - hair: 1 ( ) a lot; 2 ( ) average; 3 ( ) low; 4 ( ) absent

30 - inflorescence position in relation to stem: 1 ( ) erect; 2 ( ) pending

31 - length of the second bract (aid of calipers)

32 - width of the second bract (aid of calipers)

33 - number of bracts: inflorescence mature, i.e., pointer with two bracts open

34 - bracts outer color: different among cultivars

35 - bracts inner color: different among cultivars 
36 - rachis color: different among cultivars

37 - rachis twist: 1 ( ) presence; 2 ( ) absence

38 - rachis stiffness: 1 ( ) presence; 2 ( ) absence

39 - perianth base color: 1 ( ) white; 2 ( ) cream; 3 ( ) yellow

40 - presence of anthocyanin on perianth: 1 ( ) at the baseline; 2 ( ) presence of stripes; 3 ( ) uniform color; 4 ( ) missing

41 - sepal color

42 - petal color

43 - ovary color, immature fruit

44 - presence of pollen: 1 ( ) presence; 2 ( ) absence

45 - blooming period: 1 ( ) short $(<5$ months); 2 ( ) average $(5<$ months $<8) ; 3$ ( ) long (>8 months)

From this list, 26 qualitative descriptors were selected to phenotypically characterize the Heliconia genotypes. For these descriptors, classes were assigned as absence (0) and presence (1), or other contrasting classes, such as light green and dark green, annual and seasonal, upright and pendent, or equal and unequal (Table 2).

Table 2. Qualitative descriptors related to the pseudostem, leaf and inflorescence from genotypes of the Federal Rural University of Pernambuco Heliconia Germplasm Collection (UFRPE-HCG).

\begin{tabular}{|c|c|c|c|}
\hline \multirow[t]{2}{*}{ Descriptors } & \multirow[t]{2}{*}{ Code } & \multicolumn{2}{|c|}{ Categories } \\
\hline & & 0 & 1 \\
\hline \multicolumn{4}{|l|}{ Pseudostem } \\
\hline Pseudostem of dark green color** & PDG & Absence & Presence \\
\hline Wax* & PW & Absence & Presence \\
\hline Hair* & PH & Absence & Presence \\
\hline Leaf & & Absence & Presence \\
\hline Wax in the petiole** & WP & Absence & Presence \\
\hline Hair on petiole** & $\mathrm{HP}$ & Absence & Presence \\
\hline Base of the petiole winged** & BPW & Absence & Presence \\
\hline Basal margin of the petiole cleft** & BMP & Absence & Presence \\
\hline Open edge of the petiole** & OEP & Absence & Presence \\
\hline Midrib underside shade of green** & MUG & Absence & Presence \\
\hline Midrib upper shade of green** & MUSG & Absence & Presence \\
\hline Wax midrib underside** & WMU & Absence & Presence \\
\hline Midrib underside hair** & MUH & Absence & Presence \\
\hline Leaf hair* & $\mathrm{LH}$ & Absence & Presence \\
\hline Wax leaves* & WH & Absence & Presence \\
\hline Dark green leaf color & DGC & Absence & Presence \\
\hline Margin of leaves shade of purple** & MLP & Absence & Presence \\
\hline Leafblade dark** & LD & Absence & Presence \\
\hline Leafblade uneven bases** & LUB & Absence & Presence \\
\hline Cut leafblade** & CLB & Absence & Presence \\
\hline Inflorescence & & Absence & Presence \\
\hline Wax* & WI & Absence & Presence \\
\hline Inflorescence position pending* & IP & Absence & Presence \\
\hline Bract leaf at the apex & BLA & Absence & Presence \\
\hline Hair in the bracts** & $\mathrm{HB}$ & Absence & Presence \\
\hline Torsion of the rachis & TR & Absence & Presence \\
\hline Stiffness of the rachis & SR & Absence & Presence \\
\hline Type of seasonal blooming* & TSB & Absence & Presence \\
\hline
\end{tabular}

*Description proposed by Loges et al. (2007) and Costa et al. (2009b). **Description based on the catalog of Musa spp descriptors, with modifications. 


\section{Data analysis}

Multivariate analyses were performed to estimate the Mahalanobis dissimilarity measure, and a dendrogram was generated using the nearest neighbor method with the program Genes, 2004 version (Cruz, 2006).

\section{RESULTS AND DISCUSSION}

\section{Qualitative descriptors}

Differences were observed in most of the 26 qualitative descriptors used among the UFRPE-HCG genotypes sampled.

\section{Pseudostem}

With respect to the descriptors related to the pseudostem, the vegetative part of the plant that is usually cylindrical and is formed by numerous overlapping leaf sheaths, the shade of dark green varied among genotypes in the outer pseudostem. This variation was classified as a shade of dark green (PDG), being present in H. rostrata (Figure 1A), H. collinsiana, $H$. psittacorum x $H$. spathorcircinata cv. Alan Carle, H. bihai cv. Kamehameha, H. bihai, $H$. stricta, H. stricta cv. Fire Bird, and H. caribaea $\mathrm{x}$ H. bihai cv. Carib Flame. With respect to the pseudostem wax (PW), H. psittacorum cv. Suriname Sassy (Figure 1B) was the only genotype among all cultivars and interspecific hybrids of $H$. psittacorum to present this descriptor. In other genotypes $(H$. wagneriana, $H$. collinsiana, $H$. bihai, $H$. latispatha $\mathrm{cv}$. Red Yellow, and $H$. caribaea x H. bihai cv. Carib Flame), the presence of PW was remarkable. Hair in pseudostem $(\mathrm{PH})$ was observed only in H. orthotricha cv. She (Figure 1C).

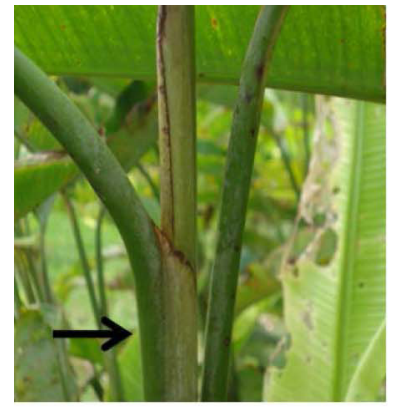

A

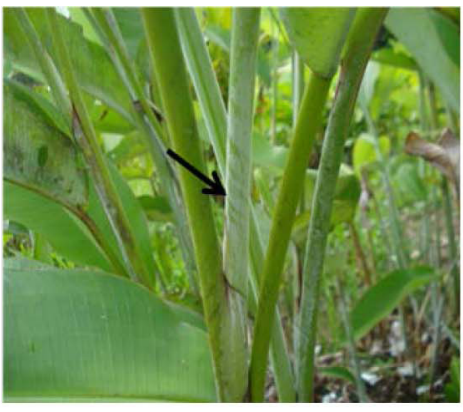

B

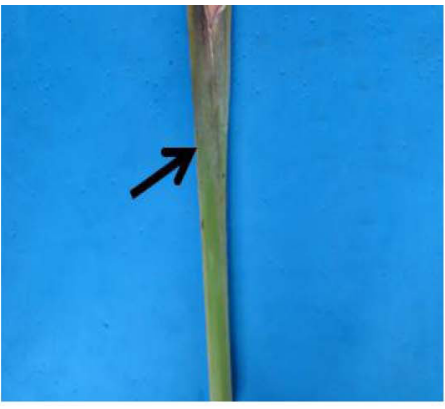

$\mathrm{C}$

Figure 1. Descriptors evaluated in Heliconia pseudostem. A. Pseudostem of dark green color - PDG (H. rostrata). B. Pseudostem wax - PW (H. psittacorum cv. Suriname Sassy). C. Pseudostem hair - PH (H. orthotricha cv. She).

\section{Leaf}

With respect to the leaves, the combinations of the petiole, leafblade, and appendices 
were considered. The presence of wax was verified in the petiole (WP) (Figure 2A) in H. wagneriana, $H$. collinsiana, H. bihai, H. caribaea $\mathrm{x} H$. bihai cv. Carib Flame, and $H$. latispatha cv. Red Yellow. Purple was observed in the margin of leaves (MLP) in all genotypes (Figure 2B), with the exception of $H$. x nickeriensis (Figure 2C). This result corroborated with the fact that its likely parent, $H$. marginata, also did not present this descriptor (Figure 2C). Wax on leaves (WH) was observed in H. collinsiana (Figure 2D) and the dark green leaf color (DGC) was observed in H. rostrata (Figure 2E).

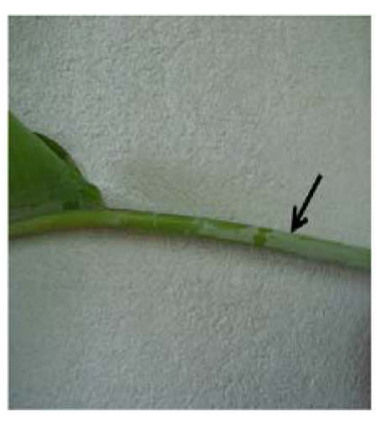

A

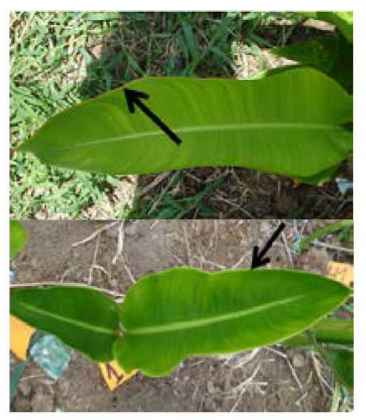

B

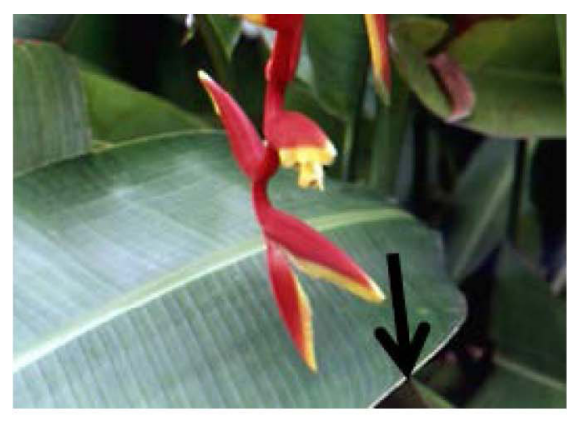

$\mathrm{C}$

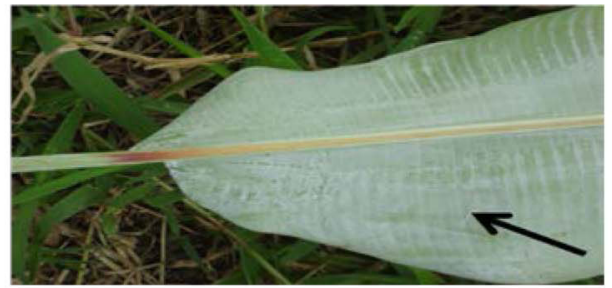

$\mathrm{D}$

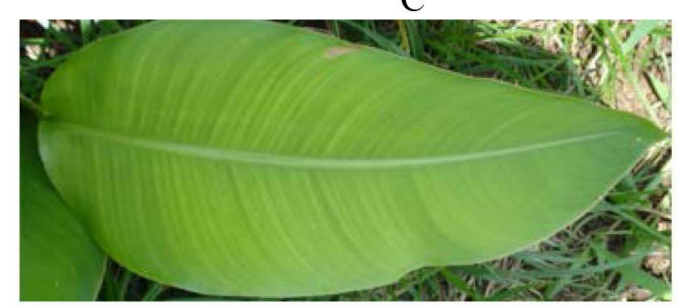

$\mathrm{E}$

Figure 2. Descriptors evaluated in Heliconia leaf. A. Wax on the petiole - CEP (H. collinsiana). B. Presence of the margin of leaves shade of purple - COM, top arrow (H. psittacorum cv. Red Gold) and absence of the margin of leaves shade of purple $(H$. x nickeriensis), lower arrow. C. Absence of the margin of leaves shade of purple $(H$. marginata). D. Wax leaves - CEF (H. collinsiana). E. Dark green leaf color - COF (H. rostrata).

The base of the petiole near the pseudostem may have a membranous expansion in its upper part, called the base of the petiole winged (BPW) (Figure 3A). With respect to the descriptor hair on petiole (HP), it was observed that most of the genotypes did not show this character, except for $H$. wagneriana, $H$. collinsiana, $H$. orthotricha $\mathrm{cv}$. She, and $H$. latispatha cv. Red-Yellow Gyro. The outside of the basal margin of the petiole cleft (BMP) (Figure 3B) was observed in $H$. rostrata, H. bihai, $H$. stricta, H. bihai cv. Kamehameha, $H$. stricta cv. Fire Bird, H. psittacorum x H. spathocircinata cv. Red Opal, and H. orthotricha cv. She. Remarkably, H. orthotricha cv. She and H. latispatha cv. Red-Yellow Gyro were the only genotypes to present hair on the underside of the midrib (MUH). H. latispatha cv. Red-Yellow Gyro was the only genotype to present leaf hair (LH) (Figure 3C).

The external deposition of anthocyanin on the top surface of the leaf is typical in some species, although the distribution of this substance is not uniform. As for the descriptors midrib underside shade of green (MUG) and the midrib upper shade of green (MUSG), it was 
observed that the genotypes $H$. episcopalis, $H$. bihai, and $H$. stricta showed the former descriptor, while only $H$. wagneriana (Figure 4A) did not show the latter descriptor. $H$. collinsi$a n a$ and $H$. caribaea $\mathrm{x} H$. bihai cv. Carib Flame presented the wax midrib underside descriptor (WMU). The descriptor leafblade uneven base (LUB) was observed in most genotypes (Figure 4B), except for $H$. wagneriana, $H$. collinsiana, $H$. bihai, $H$. stricta, $H$. stricta $\mathrm{cv}$. Fire Bird, and H. psittacorum x H. spathocircinata cv. Red Opal. The descriptor cut leafblade (CLB) was observed in H. wagneriana, H. collinsiana, and H. latispatha cv. Red-Yellow Gyro (Figure 4C).

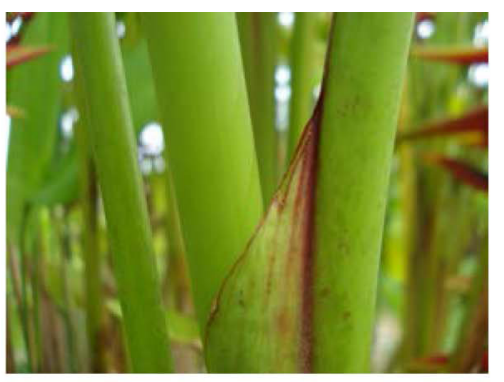

A

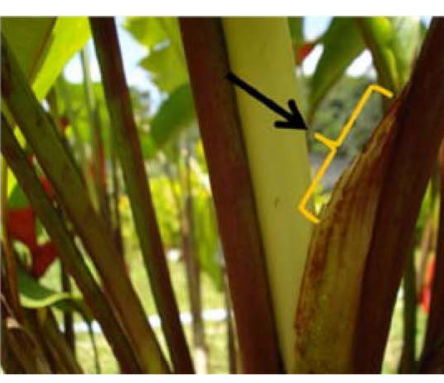

B

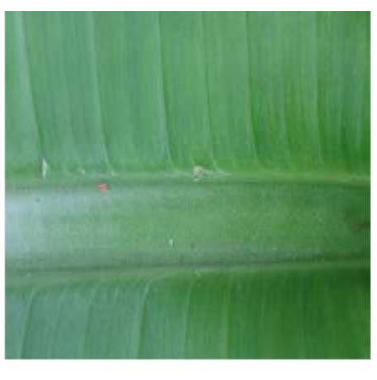

$\mathrm{C}$

Figure 3. Descriptors evaluated in Heliconia leaf. A. Base of the petiole winged - BPA (H. collinsiana). B. Basal margin of the petiole cleft - MPE (H. stricta cv. Fire Bird). C. Leaf hair - PIF (H. latispatha cv. Red-Yellow Gyro).

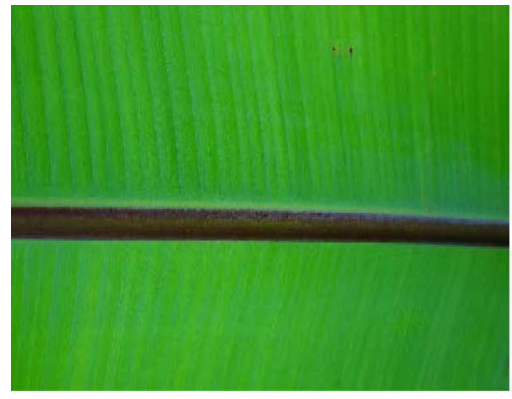

A

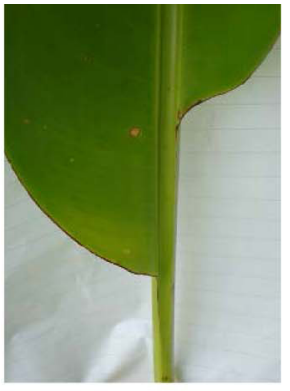

B

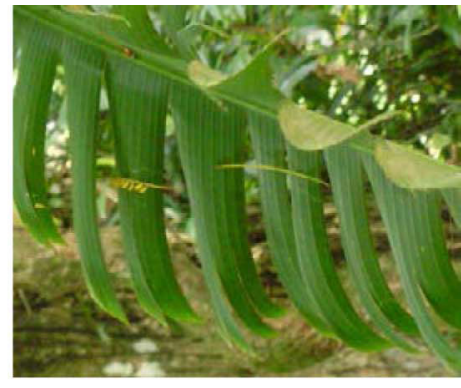

$\mathrm{C}$

Figure 4. Descriptors evaluated in Heliconia leaf. A. Midrib upper shade of green - NFS (H. wagneriana). B. Leafblade uneven bases - BLB (H. psittacorum x H. spathocircinata cv. Red Opal). C. Cut leafblade - LIB (H. collinsiana).

None of the genotypes showed either open edge of the petiole (OEP) or leafblade dark (LD), indicating that these descriptors are not useful for differentiating the Heliconia genotypes evaluated, although these descriptors do occur in other species of the genus (Loges et al., 2007).

\section{Inflorescence}

Heliconia inflorescences are composed of arranged bracts on an axis called the rachis, 
and its flowers are inserted inside these bracts. The descriptor wax on inflorescences (WI) (Figure 5A) was only evident in $H$. collinsiana and $H$. psittacorum cv. Suriname Sassy. $H$. orthotricha $\mathrm{cv}$. She stood out in group II as the only genotype to show hair on the bracts (HB) (Figure 5B). H. episcopalis, H. psittacorum cv. Red Gold, H. latispatha cv. Red-Yellow Gyro, and $H$. orthotricha $\mathrm{cv}$. She presented bract leaf at the apex (BLA) (Figure 5C and D). Regarding the descriptor seasonal blooming (TSB), most of the genotypes presented the annual type, which means that they bloom throughout the year. The genotypes $H$. wagneriana, $H$. bihai cv. Kamehameha, $H$. rostrata ' 10 days', $H$. collinsiana, $H$. orthotricha cv. She, and $H$. caribaea $\mathrm{x} H$. bihai cv. Carib Flame presented seasonal blooming. Four genotypes, H. rostrata, $H$. rostrata ' 3 days', $H$. rostrata ' 10 days', and $H$. collinsiana had the descriptor inflorescence position pending (IP). Finally, with respect to torsion of the rachis (TR), four genotypes, $H$. pseudoaemygdiana, H. bihai cv. Kamehameha, H. psittacorum cv. Red Gold, and H. latispatha cv. Red-Yellow Gyro, presented this descriptor. It was observed that all genotypes presented stiffness of the rachis (SR).

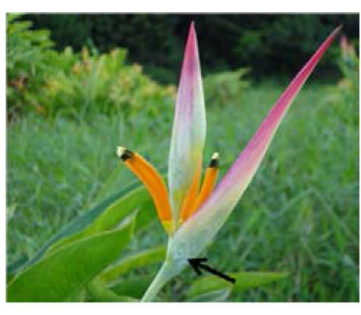

A

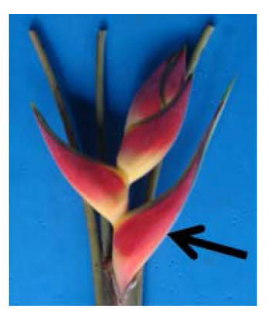

B

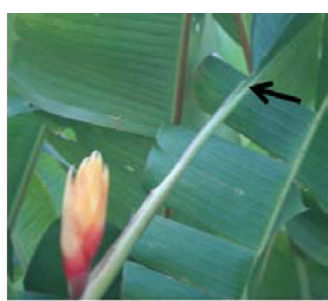

$\mathrm{C}$

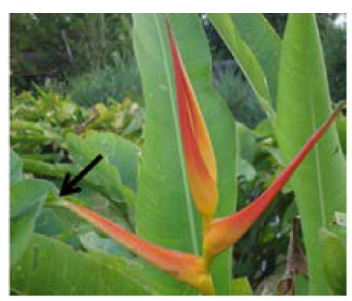

$\mathrm{D}$

Figure 5. Descriptors evaluated for Heliconia inflorescence. A. Wax inflorescence - CEI (H. psittacorum cv. Suriname Sassy). B. Hair in the bracts (PIB) (H. orthotricha cv. She). C. Bract leaf at the appex (H. episcopalis). D. Bract leaf at the appex (H. latispatha cv. Red-Yellow Gyro).

Qualitative descriptors of the flowering stem that best differentiated the genotypes were: pseudostem dark green color (PDG) and wax (PW); wax in the petiole (WP), petiole hair (HP), basal margin of the petiole cleft (BMP); midrib underside shade of green (MUG), wax midrib underside (WMU), dark green leaf color (DGC), leafblade uneven bases (LUB), and cut leafblade (CLB); inflorescence wax (WI), inflorescence position pending (IP), bract leaf at the apex (BLA), torsion of the rachis (TR), and type of seasonal blooming (TSB).

Although other qualitative descriptors related to the leaf were not relevant in differentiating the 22 evaluated Heliconia genotypes, such as midrib upper shade of green (MUSG), midrib underside hair (MUH), leaf hair (LH), wax leaves (WH), margin of leaves shade of purple (MLP), open edge of the petiole (OEP), leafblade dark (LD), and stiffness of the rachis (SR), these can nonetheless be suggested for an extended list of Heliconia descriptors because they are known to occur in other species.

In general, qualitative descriptors of the flowering stem are an important tool in measuring the variability of the genus Heliconia, since the results can be applied in the preparation of a catalog that may promote the best understanding of the economic potential of Heliconia germplasm collections, saving time, and providing research material, as well as contributing valuable information for the conservation and breeding of this genus. 


\section{Phenotypic diversity}

A dissimilarity matrix was generated from the values attributed (Table 3 ) to contrasting classes of Heliconia qualitative descriptors (Table 4). The greatest dissimilarity rate was $90 \%$ between the most genetically distant genotypes $H$. pseudoaemygdiana and $H$. psittacorum cv. Red Gold. The lowest dissimilarity rate was $17 \%$ for genotypes $H$. wagneriana and $H$. rostrata, indicating that they are genetically the closest among the studied genotypes.

Based on this matrix data and using the hierarchical nearest neighbor method, the dendrogram was generated, in which the $\mathrm{x}$-axis depicts the percentage of the distance between the genotypes and the y-axis depicts the 22 genotypes (Figure 6). The dendrogram revealed two main groups (GI and GII). Group GI was composed only by $H$. psittacorum cv. Suriname Sassy. Group GII, the most representative, was formed by the other genotypes. GII was further divided into three subgroups (SG1, SG2, and SG3). The other genotypes that appeared to be isolated in the tree were: $H$. psittacorum cv. Strawberries and Cream, $H$. stricta cv. Fire Bird, H. orthotricha cv. She, H. caribaea x H. bihai cv. Carib Flame, and H. latispatha cv. Red-Yellow Gyro.

In group GII, H. orthotricha cv. She formed an isolated group in the dendrogram, and it was also the only genotype to show hair in pseudostem $(\mathrm{PH})$ and hair in the bracts (HB).

In subgroup SG1, genotypes $H$. wagneriana, $H$. rostrata, $H$. rostrata '10 days', H. rostrata ' 3 days', H. psittacorum x H. spathocircinata cv. Alan Carle, and H. bihai cv. Kamehameha all showed erect inflorescences on the same plane, predominant red color in the bracts (Loges et al., 2007; Costa et al., 2009b), and belong to the Heliconia subgenus and Heliconia section (Kress et al., 1993). It is noteworthy that the presence of the following qualitative descriptors were observed in these genotypes: hair in pseudostem $(\mathrm{PH})$; midrib underside shade of green (MUG), hair on the underside of the midrib (MUH), margin of the leaves shade of purple (MLP), leaf hair (LH), and wax leaves (WH); bract leaf at the apex (BLA), and wax (CIS).

In subgroup SG2, the genotypes $H$. collinsiana, H. episcopalis, H. pseudoaemygdi$a n a$, and $H$. psittacorum formed a group, along with cultivars and interspecific hybrids such as cv. Golden Torch, cv. Golden Torch Adrian, cv. Red Gold, cv. Red Opal and H. x nickeriensis, which were all characterized by predominant yellow in their bracts (Loges et al., 2007). These genotypes showed the following qualitative descriptors: hair in pseudostem $(\mathrm{PH})$; base of the petiole winged (BPW), midrib upper shade of green (MUSG), midrib underside hair (MUH), and leaf hair $(\mathrm{LH})$.

Subgroup SG3 was composed of $H$. bihai and H. stricta, which were both characterized by large, upright inflorescence on a single plane and red color bracts (Loges et al., 2007; Costa et al., 2009b), and they both belong to the Heliconia subgenus and Heliconia section (Kress et al., 1993). Only two qualitative descriptors were not common between these two genotypes: wax pseudostem (PW) and dark green leaf color (DGC).

The results showed that the use of qualitative descriptors with the application of multicategorical variables assessed by the hierarchical nearest neighbor method was adequate to study the phenotypic diversity among Heliconia genotypes. These results will be applied for the preparation of a catalog for this culture, for the selection of different genotypes with characteristics most promising for crosses, and for characterization of new genotypes introduced in germplasm collections. 


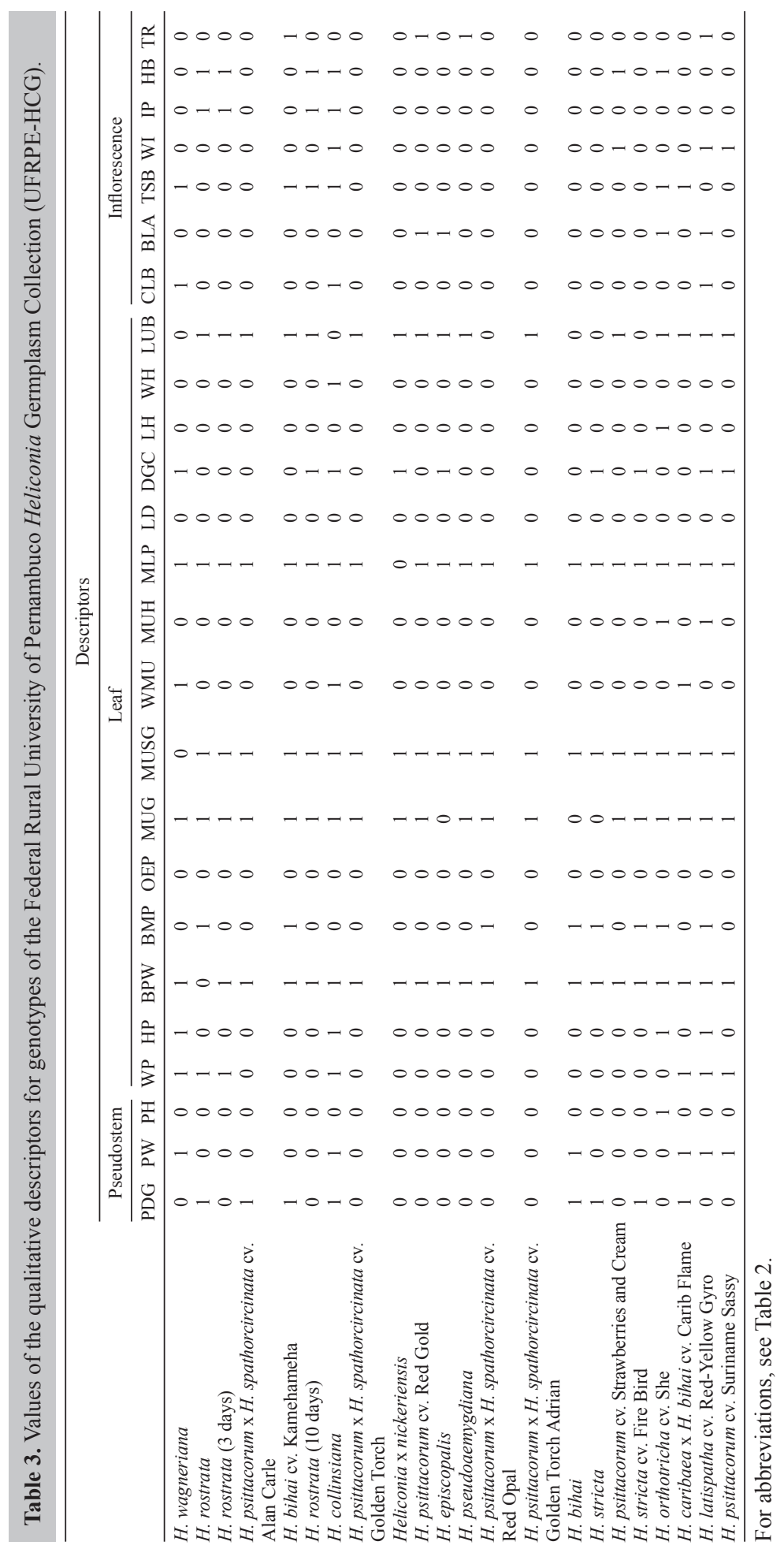


W.N.R. Guimarães et al.

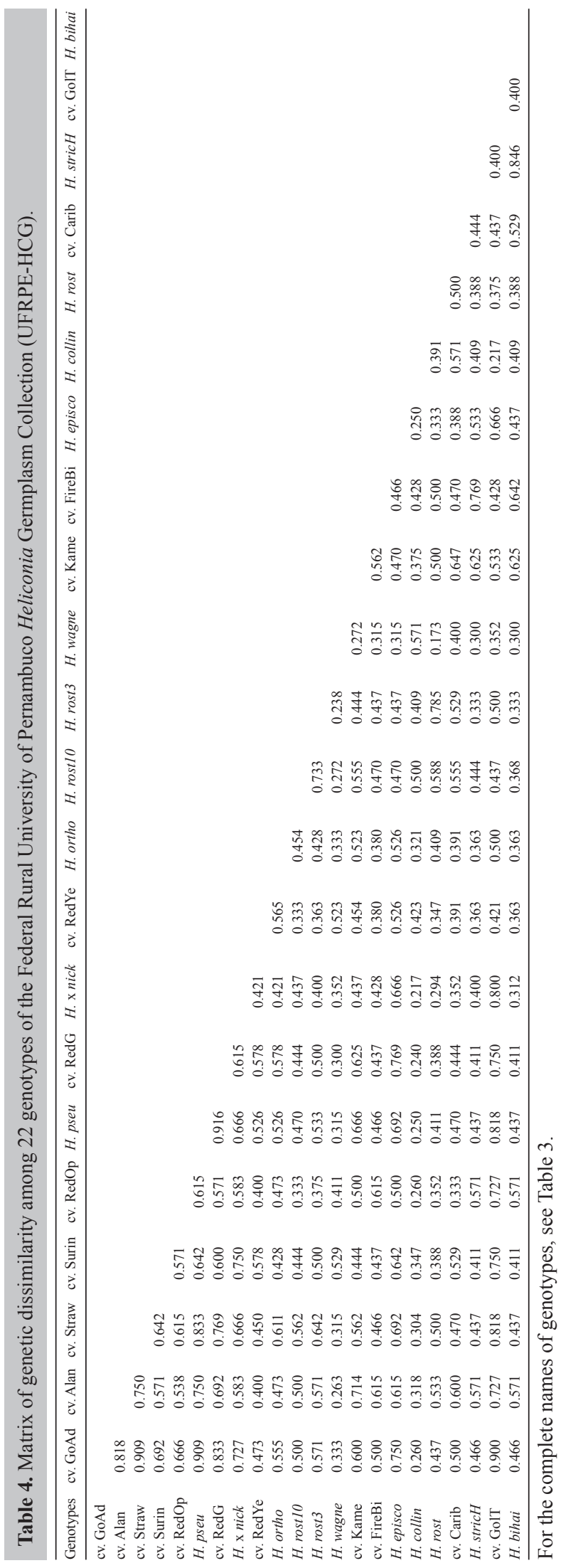




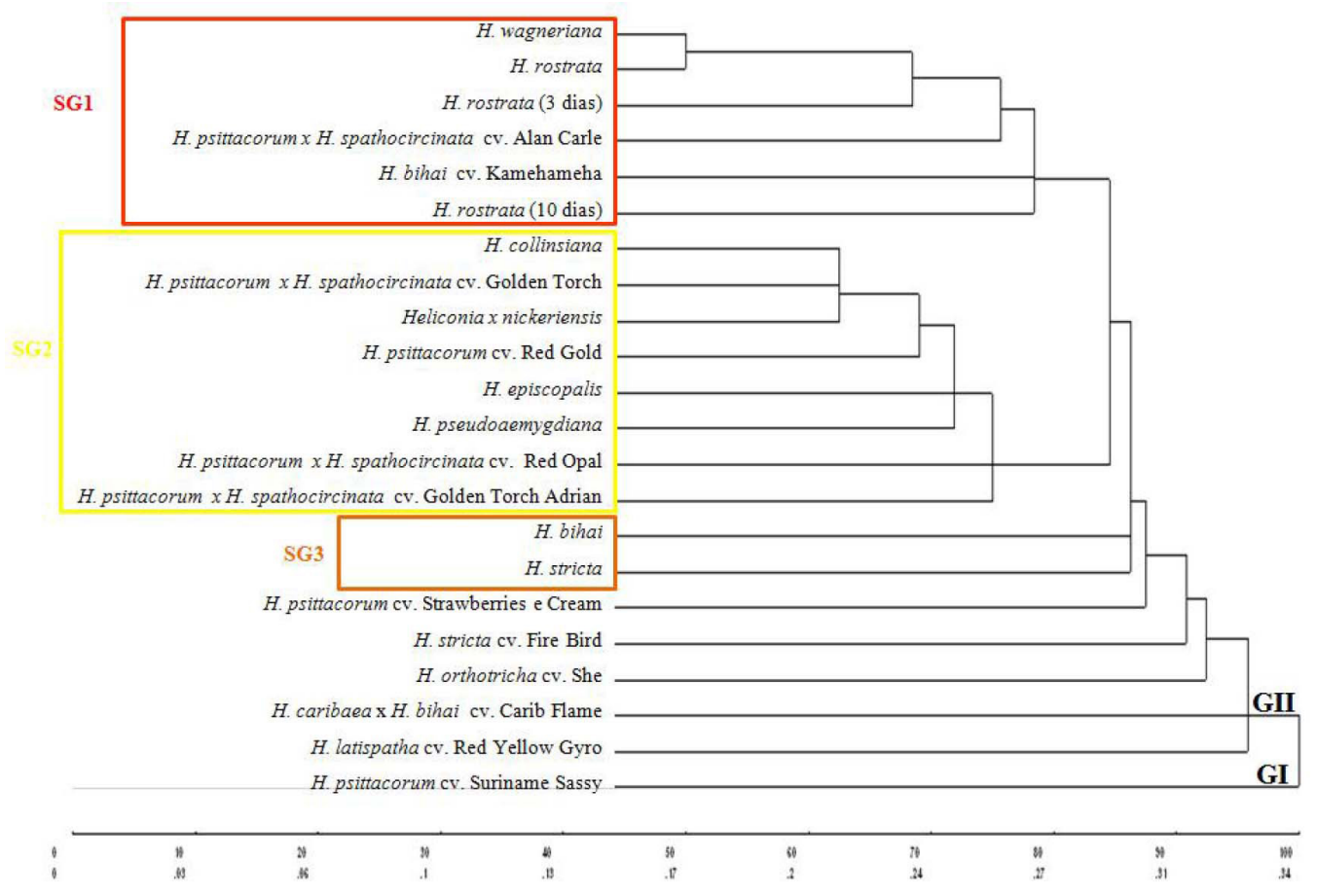

Figure 6. Dendrogram of genetic dissimilarity among the 22 genotypes of the Federal Rural University of Pernambuco Heliconia Germplasm Collection (UFRPE-HCG), using hierarchical method of the nearest neighbor. SG1 = subgroup 1; SG2 = subgroup 2; SG3 = subgroup 3.

\section{ACKNOWLEDGMENTS}

The authors thank the National Council of Scientific and Technological Development $(\mathrm{CNPq})$ and the Coordination for the Improvement of Higher Education (CAPES) for a scholarship granted to W.N.R. Guimarães, the BNB for financial support, the Bem-Te-Vi Farm, the RECIFLORA association, and trainees of the UFRPE Floriculture Laboratory.

\section{REFERENCES}

Berry F and Kress WJ (1991). Heliconia: An Identification Guide. Smithsonian Institution Press, Washington.

Castro CEF, May A and Gonçalves C (2006). Nomenclature review of species of genus Heliconia (Heliconiaceae). Rev. Bras. Hortic. Ornam. 13: 38-62.

Castro CEF (2010). Ornamentals Zingiberales: diversifying the tropical floriculture. Rev. Bras. Hortic. Ornam. 28.

Castro CEF, Gonçalves C and May A (2007). Heliconia species as cut flower. Rev. Bras. Hortic. Ornam. 12: 87-96.

Costa AS, Loges V, Castro ACR, Bezerra GJS, et al. (2007). Genetic variability and correlations among traits of cultivars and hybrids Heliconia psittacorum. Rev. Bras. Cienc. Agr. 2: 187-192.

Costa AS, Loges V, Castro ACR, Guimarães WNR, et al. (2009a). Heliconia genotypes under partial shade: I. Shooting and blooming. Acta Hort. 813: 171-176.

Costa AS, Loges V, Castro ACR and Guimarães WNR (2009b). Heliconia genotypes under partial shade: II. Evaluation of flowering stems. Acta Hort. 813: 171-176.

Criley RA (2000). Seasonal flowering patterns for heliconia shown by grower records. Acta Hort. 541: 159-166. 
Cronquist A (1981). An Integrated System of Classification of Flowering Plants. Columbia University Press, New York. Cruz CD (2006). Genes Software: Multivariate Analysis and Simulation. UFV, Viçosa.

Cruz CD and Carneiro PCS (2003). Biometric Models Applied to Genetic Improvement. Viçosa.

de Vicente MC, Guzmán FA, Engels J and Ramanatha RAOV (2005). Genetic Characterization and its use in Decision Making for the Conservation of crop Germplasm. The Role of Biotechnology, Turin, 121-128.

IPGRI (International Plant Genetic Resources Institute) (2001). The Design and Analysis of Evaluation Trials of Genetic Resources Collections. A guide for genebank managers. IPGRI Tech. Bull. 4

ITEP (2008). Pernambuco Institute of Technology. Available at [http://www.itep.br/lamepe.ASP]. Accessed May 14, 2008. ]

Kress WJ, Betancur J, Roesel CS and Echeverry BE (1993). Lista preliminar de las Heliconias de Colombia y cinco espécies nuevas. Caldasia 17: 183-197.

Loges V, Castro ACR, Costa AS, Guimarães WNR, et al. (2007). Ornamental attributes of Heliconia plants for landscape design in Brazil. Acta Hort. 743: 75-80.

Rocha FHA, Costa AS, Aragao FAS and Santos VF (2010). Genetic study with Heliconia psittacorum and interspecific hybrids. Crop Breed. Appl. Biot. 10: 282-288.

Silva SO, Carvalho PCL, Sheroherd K and Alves EJ (1999). Catalog of Banana Germplasm (Musa spp). Embrapa Mandioca e Fruticultura, Documentos, 90. 